GRASAS Y ACEITES 68 (4)

October-December 2017, e223

ISSN-L: 0017-3495

doi: http://dx.doi.org/10.3989/gya.0666171

\title{
Frying performance of two virgin oils from Cornicabra olives with different ripeness indices
}

\author{
R. Olivero-David ${ }^{\mathrm{a}, \mathrm{b}}$, C. Mena ${ }^{\mathrm{a}}$, F.J. Sánchez-Muniz ${ }^{\mathrm{b},}$, M.Á. Pérez-Jiménez ${ }^{\mathrm{a}}$, F. Holgado $^{\mathrm{c}}, \mathrm{S}^{\mathrm{S}}$ Bastida $^{\mathrm{b}}$ \\ and J. Velasco $\mathrm{d}, \bowtie$ \\ ${ }^{a}$ Instituto Madrileño de Investigación y Desarrollo Rural, Agrario y Alimentario (IMIDRA). Carretera Nacional 2, km 38,200. \\ Alcalá de Henares, 28800-Madrid, Spain. \\ ${ }^{\mathrm{b}}$ Departamento de Nutrición y Bromatología I (Nutrición). Facultad de Farmacia. Universidad Complutense de Madrid, Plaza \\ Ramón y Cajal s/n, 28040-Madrid Spain. \\ 'Instituto de Ciencia y Tecnología de los Alimentos (ICTAN). Consejo Superior de Investigaciones Científicas (CSIC). José Antonio \\ Novais 10. 28040-Madrid, Spain \\ ${ }^{\mathrm{d}}$ Instituto de la Grasa. Consejo Superior de Investigaciones Científicas (CSIC). Campus Universidad Pablo de Olavide. E46. \\ Carretera de Utrera, km 1. 41013-Sevilla, Spain. \\ ${ }^{\square}$ Corresponding authors: frasan@farm.ucm.es; jvelasco@ig.csic.es
}

Submitted: 14 June 2017; Accepted: 15 September 2017

SUMMARY: The frying performance of two virgin olive oils (VOO) from Cornicabra olives of different ripeness indices, 2.08 for VOO1 and 4.13 for VOO2, was evaluated. Thermal, oxidative and hydrolytic alterations were determined throughout 40 frying operations with potatoes. The initial oils showed similar fatty acid compositions and oxidative stability indices as determined by Rancimat, but VOO1 presented higher amounts of total polyphenols and tocopherols. The oils showed high and similar frying performance. No significant differences in the levels of polar compounds (PC) were found between the two oils during frying. Therefore, the frying stability of Cornicabra VOOs appears to be unconnected with olive fruit ripeness. The limit of degradation at $25 \% \mathrm{PC}$ as established in different countries was calculated to occur at 55 frying operations in the two oils. As oil toxicity is related to the levels of compounds formed, the use of Cornicabra VOOs for frying is highly recommended.

KEYWORDS: Cornicabra olive fruit; Frying; Oxidative stability; Potatoes; Ripeness index; Virgin olive oil

RESUMEN: Rendimiento en fritura de dos aceites vírgenes de aceitunas Cornicabra con diferentes índices de maduración. En el presente trabajo se evalúa el comportamiento de fritura de dos aceites de oliva virgen (VOO) obtenidos de aceitunas de la variedad Cornicabra con diferentes índices de maduración, 2,08 para VOO1 y 4,13 para VOO2. A lo largo de 40 operaciones de fritura con patatas se determinaron las alteraciones térmicas, oxidativas e hidrolíticas de los aceites. Los aceites iniciales presentaron composiciones de ácidos grasos e índices de estabilidad oxidativa determinados en Rancimat similares entre sí. Sin embargo, las cantidades de fenoles totales y tocoferol fueron más altas para VOO1. Los aceites mostraron una eficacia en fritura elevada y similar. No se encontraron diferencias significativas en los niveles de compuestos polares (PC) durante la fritura entre los dos aceites. Por tanto, la estabilidad en condiciones de fritura de los dos aceites Cornicabra no parece estar relacionada con el estado de maduración de las aceitunas. El límite de degradación de $25 \%$ de PC establecido en diferentes países se calculó por extrapolación de resultados, alcanzándose éste a las 55 operaciones de fritura para los dos aceites. Debido a que la toxicidad está relacionada con los niveles de compuestos formados, el uso en fritura de aceites de oliva virgen de la variedad Cornicabra es altamente recomendado.

PALABRAS CLAVE: Aceite de oliva virgen; Aceitunas Cornicabra; Estabilidad oxidativa; Índice de madurez; Fritura; Patatas ORCID ID: Olivero-David R http://orcid.org/0000-0003-1509-6669, Mena C http://orcid.org/0000-0002-7611-8940, Sánchez-Muniz FJ http://orcid.org/0000-0002-2660-5126, Pérez-Jiménez MA http://orcid.org/0000-0002-0196-1642, Holgado F http://orcid.org/0000-0003-4950-5950, Bastida S http://orcid.org/0000-0002-2188-5966, Velasco J http:// orcid.org/0000-0003-4206-3037

Citation/Cómo citar este artículo: Olivero-David R, Mena C, Sánchez-Muniz FJ, Pérez-Jiménez MÁ, Holgado F, Bastida S, Velasco J. 2017. Frying performance of two virgin oils from Cornicabra olives with different ripeness indices. Grasas Aceites 68 (4), e223. http://dx.doi.org/10.3989/gya.0666171

Copyright: (C2017 CSIC. This is an open-access article distributed under the terms of the Creative Commons Attribution (CC-by) Spain 3.0 License. 


\section{INTRODUCTION}

Virgin olive oil (VOO) has high stability against thermoxidation due to its high content in monounsaturated fatty acids and low levels of unsaturated fatty acids, along with the presence of minor antioxidant components such as phenolic compounds, tocopherols and sterols (Boskou, 2011). However, its composition is affected by factors such as cultivar, location, ripening, harvest period, processing and storage (Velasco and Dobarganes, 2002; Servili et al., 2004). Oils obtained from greener olives normally contain larger amounts of antioxidants than those from more mature olives, such as total polyphenols, including oleouropein, hydroxytyrosol and hydroxytyrosol derivatives, and tocopherols (Škevin et al., 2003; Yousfi et al., 2006; Conde et al., 2008). Cornicabra is a Spanish variety which normally produces oils with elevated stability to oxidation (Salvador et al., 2001a). This is due to a remarkably low content of linoleic acid and elevated amounts of total polyphenols. The influence of fruit ripening on Cornicabra virgin oil quality parameters has already been studied (Salvador et al., 2001b). Regarding those parameters related to oxidative stability, results showed that oleic acid diminished during ripeness, whereas linoleic acid and free acidity increased. The levels of natural antioxidants and the oxidative stability index presented a more complex behavior.

During frying a complex series of chemical reactions such as polymerization, oxidation and hydrolysis of triglycerides takes place (Dobarganes and Márquez-Ruiz, 2007). Oils which are very rich in essential fatty acids, i.e. linoleic and linolenic acids, can be adequate when consumed raw, but become very unstable at high temperatures originating potential toxic compounds that are ingested and partially absorbed (Dobarganes and Márquez-Ruiz, 2013). On the other hand, the culinary use of very stable oils containing high contents of saturated fatty acids (SFA) could be inadequate from a nutritional point of view (Olivero-David et al., 2011). Polar compounds (PC), triglyceride polymers (TGP), polar fatty acids (PFA) and fatty acid composition are good indicators of the quality of used frying fats and oils (Sánchez-Muniz et al., 2008; Dobarganes et al., 2000). Most European countries have established a maximum PC level of $25 \mathrm{wt} \%$. In addition, a few European countries have adopted a maximum amount of polymeric compounds of $10-12 \mathrm{wt} \%$ for oil discarding (DGF, 2000)

In a previous study on three virgin olive oils obtained from Picual olives with different ripeness indices, i.e. low, medium and high, the oil obtained from olives with low index was significantly more stable in the discontinuous frying of potatoes (Olivero-David et al., 2014). This did not differ substantially in the fatty acid composition, but presented higher amounts of total polyphenols and tocopherols, which gave rise to a higher oxidative stability as measured by the Rancimat test.

In comparison with other varieties, Cornicabra shows late maturation; both the pulp and skin remain green for a longer period (Salvador et al., $2001 \mathrm{a}, \mathrm{b})$. On the basis of a study on changes in oil quality parameters during four successive crop seasons, the best stage of maturity for Cornicabra olives has been suggested to be when the ripeness index is higher than 3.0 and lower than 4.0-4.5 (Salvador et al., 2001b). To the best of our knowledge, the influence of olive ripeness on the frying performance of Cornicabra virgin oils has not yet been studied. Cornicabra and Picual are known to be two Spanish olive varieties whose virgin oils normally present elevated stability to oxidative degradation (Salvador et al., 2001a). As it seems to be for Picual virgin oils, it would be of great industrial interest to get to know whether the oils of Cornicabra variety also present better frying performance when they come from olives with low ripeness indices (Olivero-David et al., 2014).

The main aim of the present study was to evaluate the frying performance of two Cornicabra virgin oils obtained from olives with very different ripeness indices. Thermoxidative and hydrolytic alterations, polar and non-polar fatty acid methyl esters, the contents of total polyphenols and tocopherols and oxidative stability in Rancimat were evaluated during the discontinuous frying of fresh potatoes. In addition, the theoretical number of frying operations at which the oils must be discarded was calculated.

\section{MATERIALS AND METHODS}

\subsection{Olive harvesting, ripeness index and oil elaboration}

Olives of Cornicabra variety were harvested during the 2012/13 olive season in the Agricultural Experimental Station "La Chimenea", Instituto Madrileño de Investigación y Desarrollo Rural, Agrario y Alimentario (IMIDRA), located in the Autonomous Community of Madrid.

About $35 \mathrm{~kg}$ of olives were hand-picked in perfect sanitary conditions from olive trees at two ripeness stages: November 19th (VOO1) and December 31st (VOO2). The olive ripeness index was determined according to the method of Uceda and Frias (1975), based on the evaluation of the olive skin and pulp colors. Seven maturity states of the fruit were used in the evaluation: 
0, bright-green skin; 1 , green-yellowish skin; 2 , green skin with reddish spots; 3 , reddish-brown skin; 4, black skin with white flesh; 5 , black skin with $<50 \%$ purple flesh; 6 , black skin with $\geq 50 \%$ and $>100 \%$ purple flesh; and 7 , black skin and purple flesh.

Olive oils were extracted within a 24-h period using the Abencor system (MC2 Ingenierías $\mathrm{y}$ Sistemas, Sevilla, Spain). The olives were crushed with a hammer mill, the paste was mixed at $26 \pm$ $1{ }^{\circ} \mathrm{C}$ for $30 \mathrm{~min}$ and then centrifuged at $3,500 \mathrm{rpm}$ for $1 \mathrm{~min}$. The oil was separated by decantation, filtered and stored at $4{ }^{\circ} \mathrm{C}$ in the dark using amber glass bottles prior to analysis.

\subsection{Potato frying}

Domestic deep-fat fryers with a $1.1 \mathrm{~L}$ stainless steel vessel (SOLAC, Vitoria-Gasteiz, Spain) were used for potato frying. Spunta variety potatoes (Valencia, Spain) were fried. The initial surface-to-volume ratio of the oil was $0.20 \mathrm{~cm}^{-1}$ $\left(225 \mathrm{~cm}^{2} / 1100 \mathrm{~cm}^{3}\right)$. The ratio between the amount of potatoes and the volume of frying oil was kept at $183 \mathrm{~g} / \mathrm{L} .1 \mathrm{~L}$ during 40 repeated frying operations by replenishing every five frying operations with unused oil in order to maintain, insofar as possible, a constant oil-to-food ratio. The oils were heated for $10 \mathrm{~min}$ till $180{ }^{\circ} \mathrm{C}$ and left for $8 \mathrm{~min}$. The potatoes were cut into $2 \mathrm{~mm}$ thick slices using a domestic potato slicer, introduced into the oil at $180^{\circ} \mathrm{C}$ and fried for $6 \mathrm{~min}$. The oil was left to cool to $30-35{ }^{\circ} \mathrm{C}$ between same-day frying operations. The cooling time was approximately $4 \mathrm{~h}$ between frying operations. On the basis of a previous study (Bastida and Sánchez-Muniz, 2001), a total of 40 frying operations at the rate of 4 fryings per day were performed with each VOO. The total frying time and the entire operation time per day were $24 \mathrm{~min}$ and $13 \mathrm{~h}$, respectively. The whole procedure was performed in duplicate using two fryers for each VOO. Thirty-five $\mathrm{mL}$ oil from each of the two fryers were taken after 10, 20,30 and 40 frying operations and kept frozen at $-20{ }^{\circ} \mathrm{C}$ until analysis.

\subsection{Fatty acid composition}

The analysis of fatty acid composition of the oils was performed by GC after derivatization to fatty acid methyl esters (FAME) with $2 \mathrm{M} \mathrm{KOH}$ in methanol at room temperature (IUPAC, 1992).

The absolute amount of individual FAME was calculated by multiplying the percentage area of each fatty acid methyl ester by the amount of the unaltered FAME fraction expressed as parts per unit giving equivalent results to those obtained using an internal standard (Olivero-David et al., 2014).

\subsection{Analysis of polar compounds (PC)}

Total PC in the fresh oils and after being used in frying were determined by adsorption chromatography (Dobarganes et al., 2000). One gram of oil was separated in a silica-packed chromatography column using $150 \mathrm{~mL}$ of hexane:diethyl ether $(90: 10, \mathrm{v} / \mathrm{v})$ and $150 \mathrm{~mL}$ of diethyl ether to elute the non-polar and polar fractions, respectively. The amount of the non-polar fraction was determined gravimetrically and that of the polar fraction by weight difference.

\subsection{High-performance size-exclusion chromatography (HPSEC) analysis}

To obtain further information about changes due to thermoxidation and hydrolysis during frying, an HPSEC analysis of the polar fraction was performed following a slight modification of the IUPAC method (Dobarganes et al., 2000). A solution of the polar fraction in tetrahydrofuran (10$15 \mathrm{mg} / \mathrm{mL}$ ) was analyzed in a High-Performance Liquid Chromatograph (HPLC) (Agilent 1100 series, Madrid, Spain) equipped with a $20-\mu \mathrm{L}$ loop, two 300 $\mathrm{mm} \times 7.5 \mathrm{~mm}$ i.d. (5 $\mu \mathrm{m}$ particle size), 0.01 and 0.05 $\mu \mathrm{m}$ PL gel columns (Agilent, Madrid, Spain), connected in series, operating at $40^{\circ} \mathrm{C}$, and a refractive index detector (Agilent Technologies 1260 infinity, Madrid; Spain). HPLC-grade tetrahydrofuran was used as the mobile phase with a flow rate of 1 $\mathrm{mL} / \mathrm{min}$. Triglyceride oligomers (TGO), triglyceride dimers (TGD), oxidized triglycerides (OTG), diglycerides (DG), monoglycerides (MG) and free fatty acids (FFA) were quantified in the PC fraction. Hydrolytic compounds (HC) were calculated as the sum of DG, MG and FFA, while thermoxidation compounds (TC) were calculated as the sum of TGO, TGD and OTG. Polymers were calculated as the sum of TGD and TGO.

\subsection{Isolation and quantification of the altered and unaltered FAME fractions}

Samples of the unused and used frying oils were saponified with $0.5 \mathrm{M} \mathrm{NaOH}$ in ethanol by applying reflux heating during $10 \mathrm{~min}$. Then methylation was performed according to the AOAC (1995) using $20 \% \mathrm{BF}_{3}$ in methanol with reflux heating during $15 \mathrm{~min}$. After methylation, $1 \mathrm{~g}$ of sample was separated by adsorption chromatography on silica gel using $150 \mathrm{~mL}$ of hexane/ diethyl ether $(88: 12, \mathrm{v} / \mathrm{v})$ and $150 \mathrm{~mL}$ of diethyl ether to elute the non-polar (unaltered) and polar (altered) fractions of FAME, respectively (Márquez-Ruiz et al., 1995). As outlined above for the non-polar and polar oil fractions, the amounts of the unaltered and altered FAME fractions were also determined gravimetrically.

Both FAME fractions were analyzed by HPSEC following the same analysis described above for the oil 
polar fraction. Thermal fatty acid dimers (thermalFAD) and non-oxidized fatty acid monomers (nonoxFAM) were quantified in the non-polar fraction, whereas fatty acid oligomers (FAO), oxidized fatty acid dimers (oxFAD), and oxidized fatty acid methyl esters (oxFAM) were quantified in the polar fraction (Márquez-Ruiz et al., 1995). Aliquots of both fractions $(10-15 \mathrm{mg} / \mathrm{mL}$ tetrahydrofuran) were analyzed in the same HPSEC device and using the same conditions described above for the oil polar fraction.

\subsection{Determination of total polyphenolic compounds}

Total phenolic compounds in unused and used frying oils were determined after methanol extraction, subsequent reaction with Folin-Ciocalteu reagent and spectrophotometrically determination at an absorption wavelength of $725 \mathrm{~nm}$ (VázquezRoncero et al., 1975).

\subsection{Determination of tocopherols}

The determination of $\alpha$ - and $\gamma$-tocopherols present in unused and used frying oils was carried out by high performance liquid chromatography according to the IUPAC method (1992).

\subsection{Oxidative stability index (OSI)}

The unused and used frying oils were analyzed by the Rancimat test to determine the OSI according to AOCS Official Method Cd 12b-92 (Firestone, 1998). A 743 Rancimat device (Metrohm Ltd, Herisau, Switzerland) was used. The OSI was obtained at $100^{\circ} \mathrm{C}$ with a continuous air flow of $20 \mathrm{~L} / \mathrm{h}$ and using $2.5 \mathrm{~g}$ oil.

\subsection{Statistical analyses}

Unless it is indicated, all determinations were made in triplicate. The Pearson product-moment correlation test was used to find relationships between parameter data and alteration markers in the oils. Linear regressions were performed to ascertain linear adjustments between the concentration of PC, different TC and HC. The SPSS 19.0 statistical program was employed. Comparisons between linear adjustments for the different compounds in the two VOOs were checked by the ANCOVA test using SAS 9.2 statistical program. Statistical significance was set at $p<0.05$.

\section{RESULTS AND DISCUSSION}

\subsection{Initial characteristics of the oils}

Following conventional Madrid-Area harvesting, Cornicabra olives were harvested at 25 and 31 weeks after flowering, presenting ripeness indices of 2.08 and
4.13 for VOO1 and VOO2, respectively. These values were relatively lower compared to those reported for other olive varieties, e.g. Picual, harvested at the same season period (Olivero-David et al., 2014).

The oils presented very similar fatty acid compositions (Table 1). As expected, the levels of linoleic and linolenic acids were relatively low. The fatty acid composition covered the expected normal range for Cornicabra virgin oils, i.e. high levels of oleic acid and low levels of linoleic and stearic acids (Salvador et al., 2001a; b). This differs from VOOs obtained from other varieties (Olivero-David et al., 2014; SánchezCasas et al., 2003). Cornicabra is one of the Spanish virgin oils with the lowest amount of linoleic acid (Alba-Mendoza, 1996). Beltrán et al. (2005) suggested that the fatty acid composition of VOOs is quantitatively affected by two main factors, the olive variety and the ripeness stage. In the present study, despite the differences in the ripeness indices no substantial differences were found in the fatty acid compositions.

The PC levels were low and of the same order in the two oils, although slightly lower for VOO1 $(1.90 \mathrm{~g} / 100 \mathrm{~g}$ oil $)$ compared to VOO2 $(2.70 \mathrm{~g} / 100 \mathrm{~g}$ oil). The values obtained reflected the good quality of both oils, as the PC levels for high-quality fresh oils normally range between 0.4 and $6.4 \mathrm{~g} / 100 \mathrm{~g}$ oil (Lumley, 1988). The PC levels of the oils agreed with previous data obtained for extra VOOs (Olivero-David et al., 2014; Romero et al., 1995). Similarly to other high-quality olive oils (Bastida and Sanchez-Muniz, 2001), DGs were the major compounds in the polar fraction, followed by OTG. VOO1 showed a lower amount of OTG $(0.39 \mathrm{~g} / 100$ $\mathrm{g}$ oil) than VOO2 (0.61 g/100 g oil). The oils did not differ substantially in the total HC. As expected,

TABLE 1. Changes in the fatty acid composition $(\mathrm{g} / 100 \mathrm{~g}$ oil) of virgin olive oils obtained from Cornicabra olives of different ripeness indices after 40 frying operations of fresh potatoes.

\begin{tabular}{lcccc}
\hline & VOO1 & VOO1 (40F) & VOO2 & VOO2 (40F) \\
\hline C16:0 & 11.1 & 11.0 & 11.0 & 11.1 \\
C16:1 & 1.1 & 1.0 & 1.0 & 1.1 \\
C18:0 & 2.5 & 2.6 & 2.7 & 2.7 \\
C18:1 & 78.4 & 73.8 & 78.6 & 73.6 \\
C18:2 & 3.1 & 2.2 & 3.4 & 2.4 \\
C18:3 & 0.7 & 0.4 & 0.7 & 0.5 \\
Others & 1.2 & 1.1 & 1.2 & 1.2 \\
SFA & 13.6 & 13.6 & 13.7 & 13.8 \\
MUFA & 79.5 & 74.8 & 79.6 & 74.7 \\
PUFA & 3.8 & 2.6 & 4.1 & 2.9 \\
\hline
\end{tabular}

VOO1, VOO2, virgin olive oils from olives with a ripeness index of 2.08 and 4.13 , respectively. Results express average values of two determinations. SFA, saturated fatty acids; MUFA, monounsaturated fatty acid; PUFA, polyunsaturated fatty acids. 
TGO and TGD were not detected. These are characteristic of oils that have been subjected to high temperatures like refined oils or used frying oils (Dobarganes et al., 1988).

The levels of total polyphenols were within those reported for Cornicabra virgin oils (Salvador et al., 2001a). VOO1 showed a remarkably greater content (273.6 $\mathrm{mg} / \mathrm{kg}$ oil) than VOO2 (61.2 $\mathrm{mg} / \mathrm{kg}$ oil). The amount of tocopherol, which was mainly constituted by $\alpha$-tocopherol and also by $\gamma$-tocopherol in trace amounts, was also higher in VOO1 $(174 \mathrm{mg} /$ $\mathrm{kg}$ oil) than in VOO2 (128 mg/kg oil). Therefore, the total amount of antioxidants, i.e. polyphenols and tocopherols, was higher in VOO1.

Both oils presented high resistance to oxidative degradation, showing OSI values greater than 20 $\mathrm{h}$ at $100{ }^{\circ} \mathrm{C}$. Despite the greater amount of antioxidants found in $\mathrm{VOO} 1$ and the fact that no substantial differences were found in the fatty acid compositions between the two oils, the oxidative stability of VOO1 $\left(\mathrm{OSI}_{100^{\circ} \mathrm{C}} 24.4 \mathrm{~h}\right)$ was comparable to that of $\mathrm{VOO} 2\left(\mathrm{OSI}_{100^{\circ} \mathrm{C}} 25.4 \mathrm{~h}\right)$. These results reflect the complexity of lipid oxidation, which depends not only on the fatty acid composition and levels of antioxidants, but also on a number of other factors (Velasco and Dobarganes, 2002).

Overall, the two oils studied with different ripeness indices presented similar fatty acid compositions, high quality and high and similar oxidative stability, but differed in the total amount of antioxidants, i.e. total polyphenols and tocopherols.

\subsection{Oils changes during repeated frying of potatoes}

As expected, decreases in the amount of oleic $(5.9 \%$ and $6.4 \%)$, linoleic $(29.0 \%$ and $29.4 \%)$ and linolenic $(42.9 \%$ and $28.6 \%)$ acids were observed in VOO1 and VOO2 after 40 frying operations, respectively. Oleic acid displayed the major decrease in absolute amounts (4.8-5.0 g/100 g of oil). Due to the great differences in the contents of oleic and linoleic acids in olive oils, significant decreases in oleic acid were not detected until linoleic acid was substantially reduced (Romero et al., 1995; 2000). The changes in oleic, linoleic and linolenic acid concentrations were negatively and linearly correlated $(p<0.05$; $p<0.001 ; p<0.001$, respectively) with the number of frying operations (data not shown), which supports studies reported by Romero et al. $(1995 ; 2000)$.

Figures 1 and 2 show the total $\mathrm{PC}$ and the TC and $\mathrm{HC}$ amounts, respectively. The PC and TC increased linearly (at least $r^{2}=0.981 ; p<0.001$ ) with the number of frying operations, whereas, in agreement with previous studies (Bastida and Sánchez-Muniz, 2001; Romero et al., 2003; Velasco et al., 2005), the HC remained constant.

The levels of total PC indicated that the two oils showed similar frying performance. No substantial differences in the total level of alteration were found between the two oils during frying (Figure 1). These results differ from those reported for Picual VOOs, which were subjected to the same experimental frying conditions of the

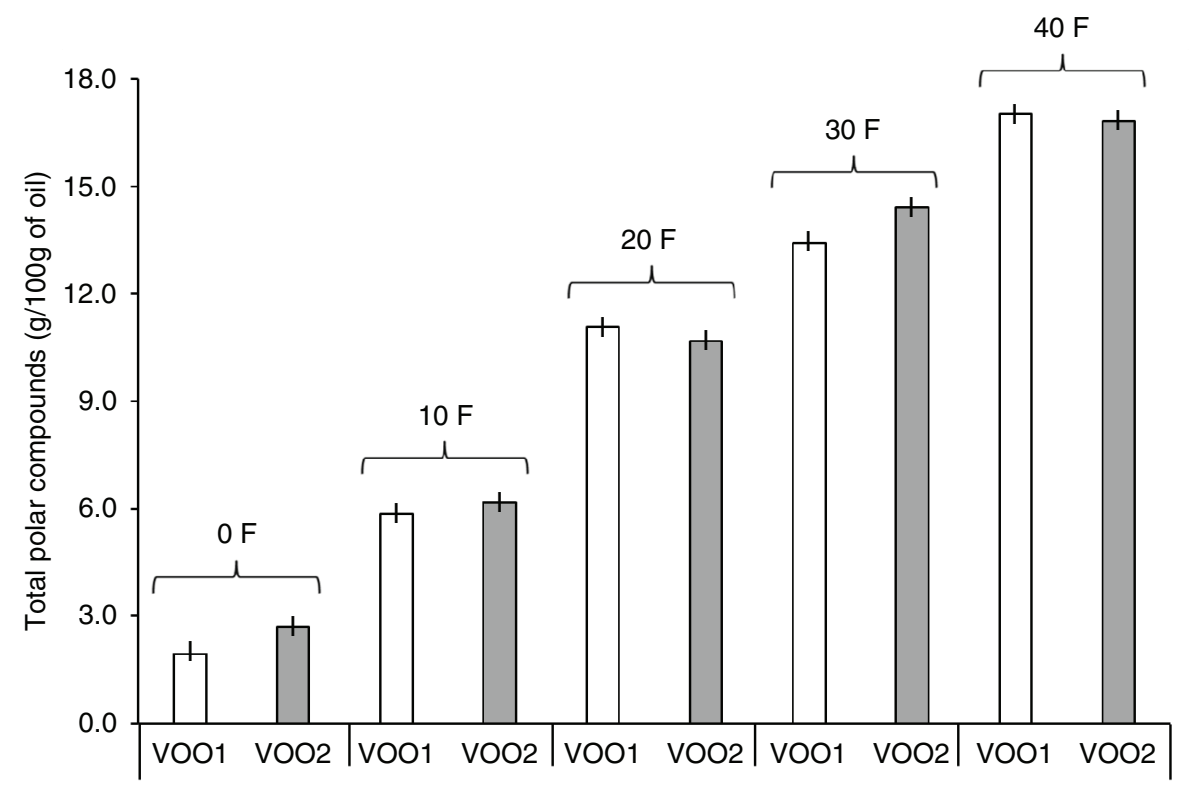

FIGURE 1. Total polar compounds ( $\mathrm{g} / 100 \mathrm{~g}$ oil) of virgin olive oils (VOOs) obtained from Cornicabra olives of two different ripeness indices when unused and after being used in 40 frying operations with potatoes. 


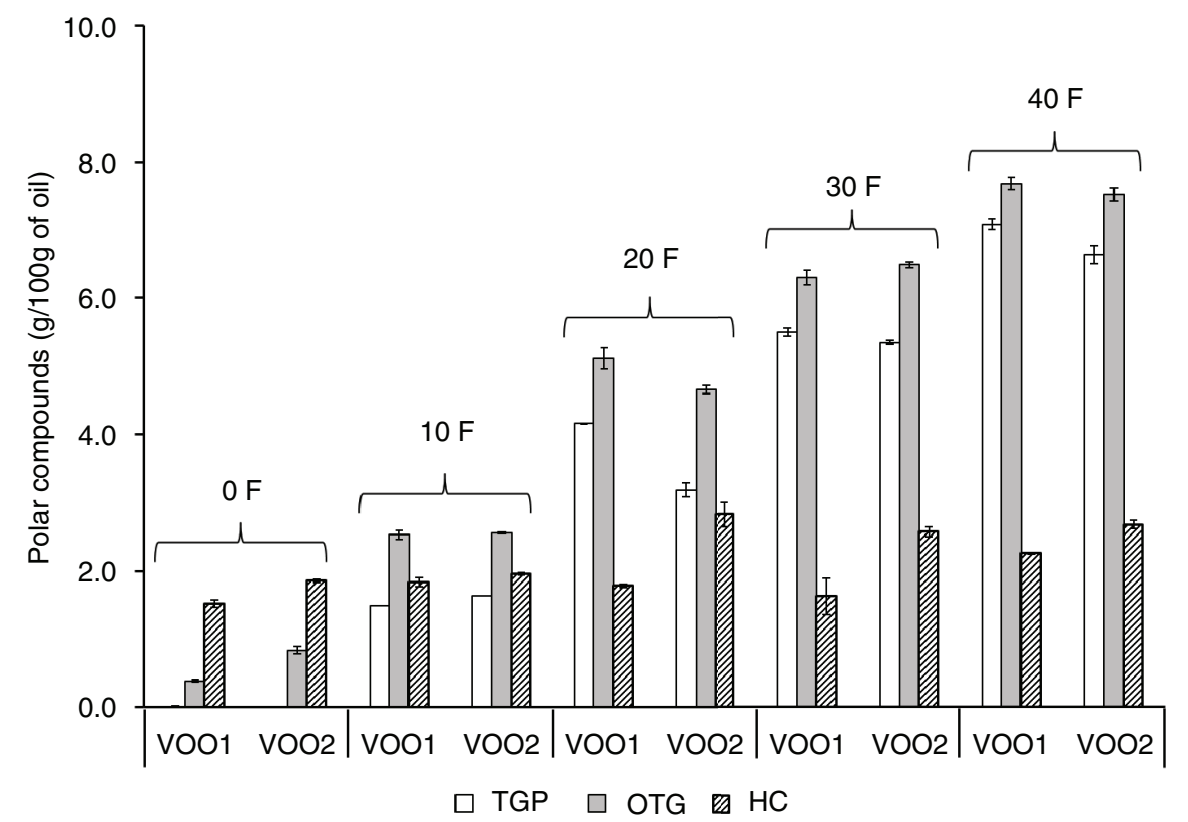

FIGURE 2. Thermoxidative and hydrolytic compounds (g/100 g oil) of the Cornicabra virgin olive oils (VOOs). TGP, triglyceride polymers; OTG, oxidized triglycerides; HC, hydrolytic compounds. TGP were calculated as the sum of triglyceride dimers and triglyceride oligomers. HC were calculated as the sum of diglycerides, monoglycerides and free fatty acids.

present study (Olivero-David et al., 2014). The oil of more mature olives exhibited quicker formation of PC, showing values that were greater in 3.5-4 g/100 g oil compared to two oils with lower ripeness index values. While no substantial differences in the fatty acid compositions were found among the three oils, the oil with the lowest ripeness index showed higher antioxidant levels, i.e. total polyphenols and tocopherols (Olivero-David et al., 2014).

The PC and TGP levels found at the end of the frying assay were not greater than $18 \mathrm{~g} / 100 \mathrm{~g}$ and $8 \mathrm{~g} / 100 \mathrm{~g}$ oil, respectively, which are far from the limits of $25 \mathrm{~g} / 100 \mathrm{~g}$ oil for total PC and $10-12 \mathrm{~g} / 100$ g oil for TGP (DGF, 2000). This is indicative of the high frying life of Cornicabra virgin oils. The values of PC agreed with those of Casal et al. (2010) in commercial extra VOO of the same cultivar. This showed the highest stability in the frying of potatoes when compared to a mixture of refined oil and VOO, and refined sunflower oil.

Previous studies suggested that oil thermoxidation changes fit to linear adjustments when frying was performed with low or null oil-turnover but to a power, logarithmic or quadratic adjustment when frequent turnover was done (Sánchez-Muniz et al., 2008). According to the linear total PC level adjustments obtained (Table 2), both VOOs would have been discarded between the 55th and $59^{\text {th }}$ frying operations, respectively. This is relevant taking into account the relatively low turnover of fresh oil performed.

Results of polar FAME are given in Figure 3. From a nutritional point of view, the evaluation of polar and non-polar fatty acyl chains of triglycerides provides valuable additional information about oil degradation (Sánchez-Muniz et al., 2008). Unlike altered triglycerides which comprise both modified and unaltered fatty chains, the analysis of polar and non-polar FAME enables us to know the quantities of the alteration compounds that are directly absorbed after digestion. During frying, the increase in altered fatty acyl chains was linearly adjusted with the number of frying operations (at least $p<0.01$ ), whereas the non-polar fraction and the non-oxFAM presented negative linear adjustments (all, $p<0.01$ ) (Table 3 ). Previously, it was suggested that $27.6 \% \mathrm{PC}$ corresponds to 8.7 to $11.3 \%$ polar-ME (Dobarganes and Márquez-Ruiz, 2007). Using 9.5\% Polar-ME as a cut-off point, the VOOs shelf-life could have been extended at least to the $64^{\text {th }}$ frying. 
Frying performance of two virgin oils from Cornicabra olives with different ripeness indices $\bullet$

TABLE 2. Linear adjustments between different thermoxidation or hydrolytic compounds ( $\mathrm{g} / 100 \mathrm{~g}$ oil) and the number of frying of fresh potatoes with virgin olive oils obtained from Cornicabra olives of different ripeness indices.

\begin{tabular}{|c|c|c|c|c|c|c|c|c|}
\hline & Samples $^{a}$ & $\mathbf{r}^{2}$ & beta & Intercept $^{b}$ & Slope $^{b}$ & $p^{c}$ & $\begin{array}{c}{\mathrm{VOO1} \mathrm{vs} \mathrm{VOO2}^{d}}_{\text {Intercept }} \\
\end{array}$ & $\begin{array}{c}\text { VOO1 vs VOO2 }^{d} \\
\text { Slope } \\
\end{array}$ \\
\hline \multirow[t]{3}{*}{$\mathrm{PC}$} & VOO1 & 0.984 & 0.992 & $\begin{array}{c}2.269(1.310 \\
3.228)\end{array}$ & $\begin{array}{c}0.381(0.338 \\
0.425)\end{array}$ & $<0.001$ & NS & NS \\
\hline & $\mathrm{VOO} 2$ & 0.991 & 0.995 & $\begin{array}{c}2.781(2.479 \\
3.287)\end{array}$ & $\begin{array}{c}0.372(0.340 \\
0.405)\end{array}$ & $<0.001$ & & \\
\hline & VOO1 & 0.973 & 0.986 & $\begin{array}{c}-0.090(-0.204 \\
-0.023)\end{array}$ & $\begin{array}{c}0.034(0.029 \\
0.039)\end{array}$ & $<0.001$ & NS & NS \\
\hline TGO & VOO2 & 0.944 & 0.971 & $\begin{array}{c}-0.092(-0.172 \\
-0.025)\end{array}$ & $\begin{array}{c}0.028(0.022 \\
0.034)\end{array}$ & $<0.001$ & & \\
\hline \multirow[t]{2}{*}{ TGD } & VOO1 & 0.979 & 0.989 & $\begin{array}{c}0.093(-0.340 \\
0.526)\end{array}$ & $\begin{array}{c}0.149(0.130 \\
0.169)\end{array}$ & $<0.001$ & NS & NS \\
\hline & VOO2 & 0.992 & 0.996 & $\begin{array}{c}0.058(-0.188 \\
0.304)\end{array}$ & $\begin{array}{c}0.142(0.131 \\
0.153)\end{array}$ & $<0.001$ & & \\
\hline \multirow[t]{2}{*}{ TGP } & VOO1 & 0.985 & 0.992 & $\begin{array}{c}0.003(-0.451 \\
0.457)\end{array}$ & $\begin{array}{c}0.183(0.163 \\
0.204)\end{array}$ & $<0.001$ & NS & NS \\
\hline & VOO2 & 0.994 & 0.997 & $\begin{array}{c}-0.034(-0.300 \\
0.232)\end{array}$ & $\begin{array}{c}0.170(0.158 \\
0.182)\end{array}$ & $<0.001$ & & \\
\hline \multirow[t]{2}{*}{ OTG } & VOO1 & 0.974 & 0.987 & $\begin{array}{c}0.689(0.078 \\
1.300)\end{array}$ & $\begin{array}{c}0.188(0.161 \\
0.216)\end{array}$ & $<0.001$ & NS & NS \\
\hline & VOO2 & 0.988 & 0.994 & $\begin{array}{c}0.916(0.535 \\
1.296)\end{array}$ & $\begin{array}{c}0.177(0.160 \\
0.194)\end{array}$ & $<0.001$ & & \\
\hline \multirow[t]{2}{*}{ DG } & VOO1 & 0.438 & 0.662 & $\begin{array}{c}1.107(0.929 \\
1.285)\end{array}$ & $\begin{array}{c}0.008(0.000 \\
0.016)\end{array}$ & 0.052 & NS & NS \\
\hline & VOO2 & 0.637 & 0.798 & $\begin{array}{c}1.369(1.127 \\
1.611)\end{array}$ & $\begin{array}{c}0.016(0.005 \\
0.027)\end{array}$ & 0.010 & & \\
\hline \multirow[t]{2}{*}{ MG } & VOO1 & 0.358 & 0.599 & $\begin{array}{c}0.052(-0.001 \\
0.105)\end{array}$ & $\begin{array}{c}0.002(0.000 \\
0.004)\end{array}$ & 0.089 & NS & NS \\
\hline & VOO2 & 0.716 & 0.846 & $\begin{array}{c}0.043(0.011 \\
0.074)\end{array}$ & $\begin{array}{c}0.003(0.001 \\
0.004)\end{array}$ & 0.004 & & \\
\hline \multirow[t]{2}{*}{ FFA } & VOO1 & 0.000 & 0.008 & $\begin{array}{c}0.419(0.321 \\
0.517)\end{array}$ & $\begin{array}{c}0.003(-0.004 \\
0.000)\end{array}$ & 0.980 & NS & NS \\
\hline & VOO2 & 0.229 & 0.687 & $\begin{array}{c}0.488(0.350 \\
0.627)\end{array}$ & $\begin{array}{c}0.007(0.004 \\
0.013)\end{array}$ & 0.041 & & \\
\hline \multirow[t]{2}{*}{$\mathrm{TC}$} & VOO1 & 0.981 & 0.991 & $\begin{array}{c}0.692(-0.317 \\
1.700)\end{array}$ & $\begin{array}{c}0.371(0.326 \\
0.417)\end{array}$ & $<0.001$ & NS & NS \\
\hline & VOO2 & 0.993 & 0.997 & $\begin{array}{c}0.882(0.320 \\
1.443)\end{array}$ & $\begin{array}{c}0.347(0.322 \\
0.372)\end{array}$ & $<0.001$ & & \\
\hline \multirow[t]{2}{*}{$\mathrm{HC}$} & VOO1 & 0.309 & 0.556 & $\begin{array}{c}1.578(1.281 \\
1.874)\end{array}$ & $\begin{array}{c}0.010(-0.003 \\
0.023)\end{array}$ & 0.120 & NS & NS \\
\hline & $\mathrm{VOO} 2$ & 0.656 & 0.810 & $\begin{array}{c}1.900(1.536 \\
2.263)\end{array}$ & $\begin{array}{c}0.025(0.009 \\
0.042)\end{array}$ & 0.008 & & \\
\hline \multirow[t]{2}{*}{$\mathrm{TC} / \mathrm{HC}$} & VOO1 & 0.871 & 0.933 & $\begin{array}{c}0.595(-0.885 \\
2.075)\end{array}$ & $\begin{array}{c}0.195(0.128 \\
0.262)\end{array}$ & $<0.001$ & NS & 0.020 \\
\hline & $\mathrm{VOO} 2$ & 0.967 & 0.984 & $\begin{array}{c}0.622(0.181 \\
1.064)\end{array}$ & $\begin{array}{c}0.122(0.102 \\
0.142)\end{array}$ & $<0.001$ & & \\
\hline
\end{tabular}

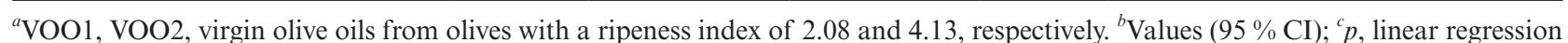
significance; ${ }^{d} p$, significant differences between linear adjustments. TGP, triglyceride polymers (oligomers + dimers); TGD, triglyceride dimers; TGO, triglyceride oligomers; OTG, oxidized triglycerides; DG, diglycerides; MG, monoglycerides; FFA, free fatty acids. Hydrolytic compounds (HC), is the sum of DG, MG and FFA. Thermoxidation compounds (TC), is the sum of TGO, TGD and OTG. 


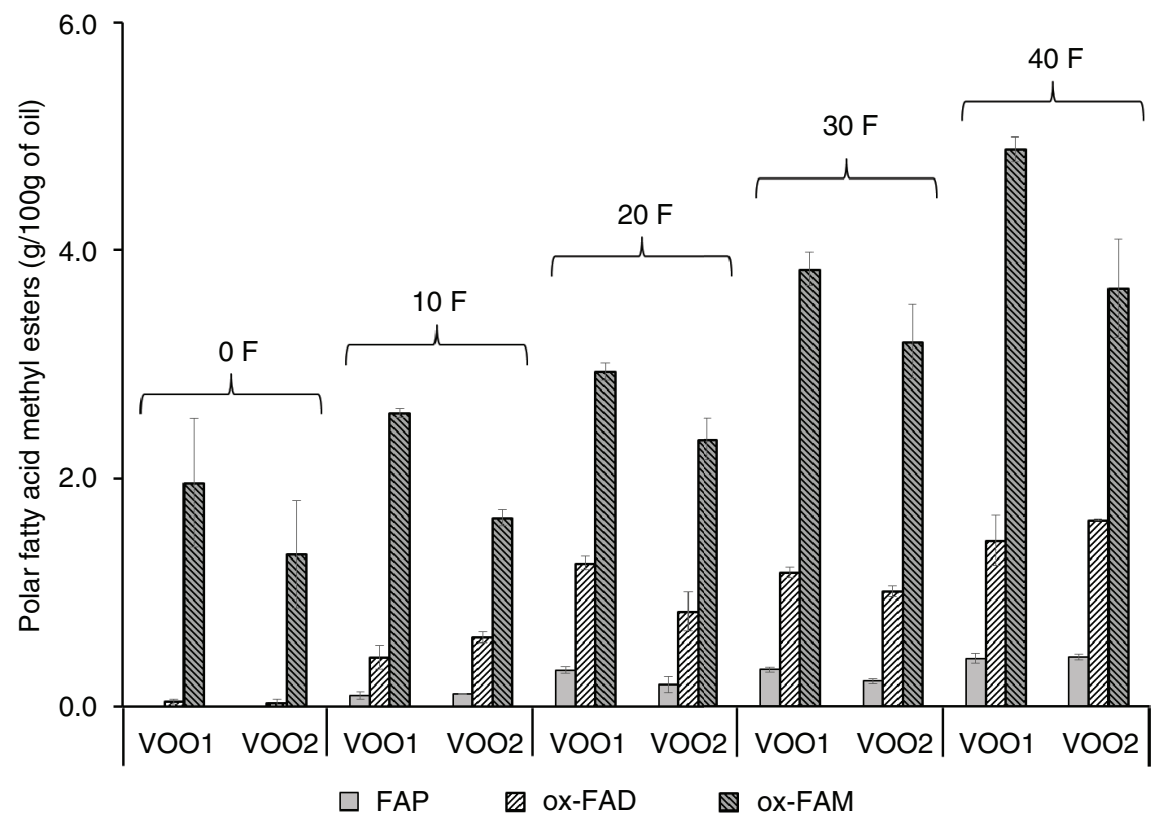

FIgURE 3. Polar fatty acid methyl esters ( $\mathrm{g} / 100 \mathrm{~g}$ oil) in the oils. FAP, fatty acid polymers; ox-FAD, oxidized fatty acid dimers; ox-FAM, oxidized fatty acid monomers.

TABLE 3. Linear adjustments between polar methyl esters, thermal fatty acid dimers, non-oxidized fatty acid monomers, fatty acid polymers, oxidized fatty acid dimers $(\mathrm{g} / 100 \mathrm{~g}$ oil) and the number of fryings of fresh potatoes with virgin olive oils obtained from Cornicabra olives of different ripeness index.

\begin{tabular}{|c|c|c|c|c|c|c|c|c|}
\hline & Samples $^{a}$ & $\mathbf{r}^{2}$ & beta & Intercept $^{b}$ & Slope $^{b}$ & $p^{c}$ & $\begin{array}{l}\text { VOO1 vs } \\
\text { VOO2 }^{d} \\
\text { Intercept }\end{array}$ & $\begin{array}{l}\text { VOO1 vs } \\
\text { VOO2 }^{d} \\
\text { Slope } \\
\end{array}$ \\
\hline \multirow[t]{2}{*}{ Polar-ME } & $\mathrm{VOO}^{a}$ & 0.979 & 0.989 & $1.994(1.649,2.339)$ & $0.117(0.103,0.132)$ & $<0.001$ & 0.038 & NS \\
\hline & VOO2 & 0.966 & 0.983 & $1.296(0.893,1.699)$ & $0.108(0.091,0.124)$ & $<0.001$ & & \\
\hline \multirow[t]{2}{*}{ Thermal-FAD } & VOO1 & 0.682 & 0.826 & $1.135(-0.183,2.452)$ & $0.097(0.043,0.151)$ & 0.003 & NS & NS \\
\hline & VOO2 & 0.616 & 0.785 & $1.360(-0.046,2.766)$ & $0.089(0.032,0.146)$ & 0.007 & & \\
\hline \multirow{2}{*}{$\begin{array}{l}\text { Non-oxidized } \\
\text { FAM }\end{array}$} & VOO1 & 0.916 & -0.957 & $96.871(95.575,98.168)$ & $-0.214(-0.267,-0.161)$ & $<0.001$ & NS & NS \\
\hline & VOO2 & 0.893 & -0.945 & $97.344(95.985,98.703)$ & $-0.197(-0.252,-0.141)$ & $<0.001$ & & \\
\hline \multirow[t]{2}{*}{ FAP } & VOO1 & 0.905 & 0.951 & $0.018(-0.051,0.087)$ & $0.011(0.008,0.013)$ & $<0.001$ & NS & NS \\
\hline & $\mathrm{VOO} 2$ & 0.903 & 0.950 & $-0.003(-0.067,0.061)$ & $0.010(0.007,0.012)$ & $<0.001$ & & \\
\hline \multirow[t]{2}{*}{ OxFAD } & VOO1 & 0.851 & 0.923 & $0.161(-0.136,0.458)$ & $0.036(0.023,0.048)$ & $<0.001$ & NS & NS \\
\hline & VOO2 & 0.939 & 0.969 & $0.102(-0.082,0.285)$ & $0.036(0.029,0.044)$ & $<0.001$ & & \\
\hline \multirow[t]{2}{*}{ OxFAM } & VOO1 & 0.934 & 0.967 & $1.815(1.439,2.192)$ & $0.071(0.056,0.087)$ & $<0.001$ & 0.049 & NS \\
\hline & VOO2 & 0.917 & 0.958 & $1.198(0.824,1.571)$ & $0.062(0.047,0.077)$ & $<0.001$ & & \\
\hline \multirow[t]{2}{*}{ Apolar-ME } & VOO1 & 0.979 & -0.989 & $98.006(97.661,98.351)$ & $-0.117(-0.132,-0.103)$ & $<0.001$ & 0.038 & NS \\
\hline & VOO2 & 0.966 & -0.983 & $98.704(98.301,99.107)$ & $-0.108(-0.124,-0.091)$ & $<0.001$ & & \\
\hline
\end{tabular}

${ }^{a} \mathrm{VOO} 1, \mathrm{VOO} 2$, virgin olive oils from olives with a ripeness index of 2.08 and 4.13 , respectively. ${ }^{b}$ Values $(95 \% \mathrm{CI}) ;{ }^{c} p$, linear regression significance; ${ }^{d} p$, significant differences between linear adjustments. Polar ME, Polar methyl esters; Thermal-FAD, Thermal fatty acid dimers; Non-oxidized FAM, Non-oxidized fatty acid monomers; FAP, Fatty acid polymers; OxFAD, Oxidized fatty acid dimers; OxFAM, Oxidized fatty acid monomers; NS, not significant.

Figure 4 shows the levels of total polyphenols and tocopherols. The concentrations of total polyphenols sharply decreased during the first 10 frying operations in the two oils, reaching undetectable levels after the $25^{\text {th }}$ frying operation. The amount of tocopherols also sharply decreased during frying, showing losses of approximately $90 \%$ in both oils after the first 5 frying operations. The tocopherol 


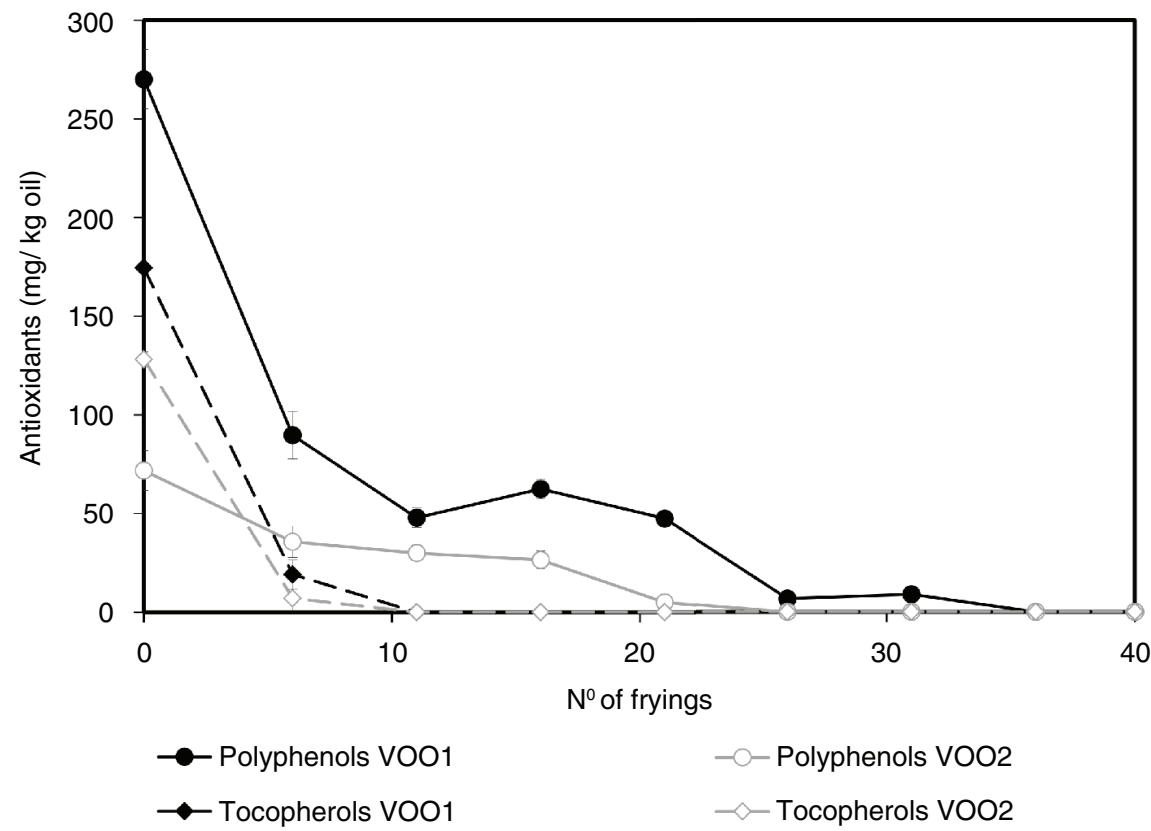

FIGURE 4. Changes in tocopherols and total polyphenols (both in $\mathrm{mg} / \mathrm{kg}$ oil) of the oils during frying.

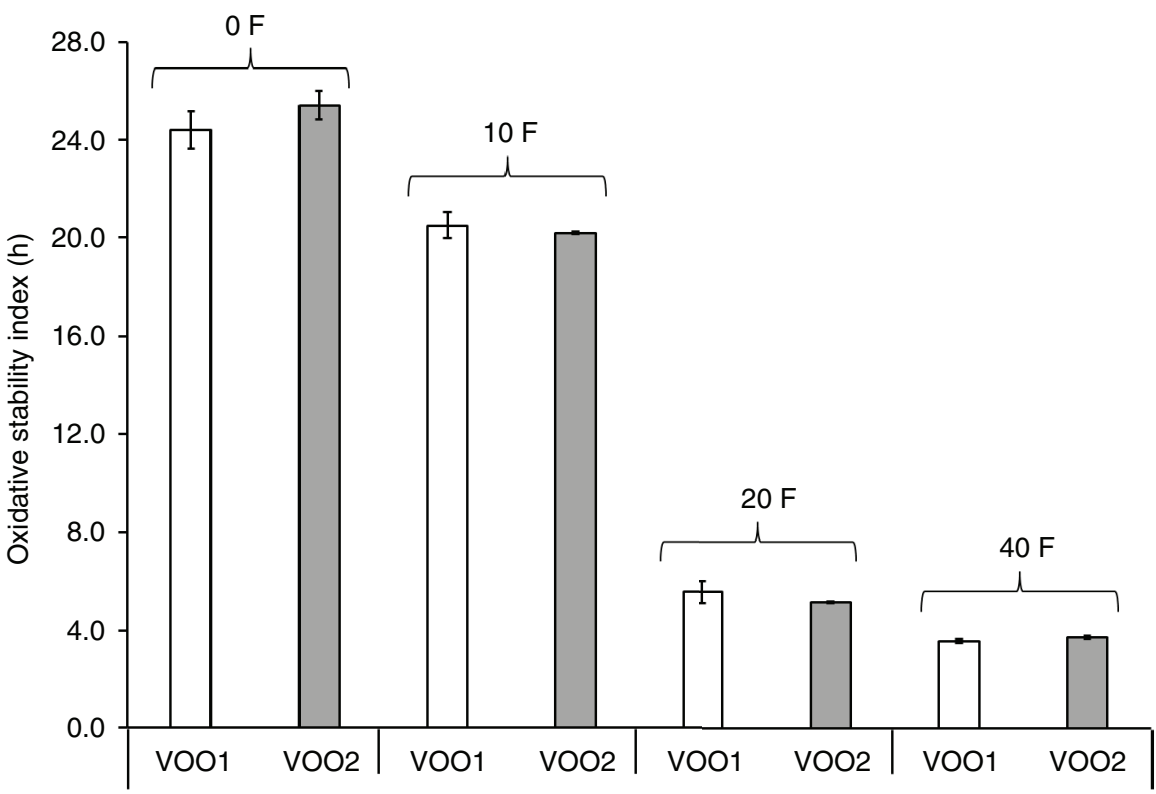

Figure 5. Changes in the oxidative stability index (h) measured in Rancimat at $100{ }^{\circ} \mathrm{C}$ after frying.

levels were undetected in the two oils after 10 frying operations.

The results in this study show the rapid degradation of natural antioxidants present in oils at the temperatures normally applied in the frying of foods. In this respect, the similar frying performance of the two oils, mainly differing in the contents of antioxidants, could be related to the rapid degradation of both polyphenols and tocopherols at frying conditions. Barrera-Arellano et al. (2002) suggested that the degradation of tocopherols at frying temperatures seems to be predominant over their antioxidative role, as the degradation of tocopherols added to different purified vegetable oils was independent of the degree of unsaturation of the oil. These authors suggested that the protection effect of naturally 
occurring tocopherols was a secondary mode of action.

As expected, the OSI values decreased progressively during frying as a consequence of the losses in antioxidants and the accumulation of oxidation compounds (Figure 5). No significant differences were found in the OSI values between the two oils throughout the frying assay. The determination of the oxidative stability of oils by the Rancimat test is a widely used method to determine the resistance to oxidation at the conditions of the test, demanding short analysis time. The oxidative stability index provides information about the oxidative behaviour of oils at room or moderate temperatures if oxygen is not a limiting factor. On the other hand, this index does not allow us to get to know the performance of an oil at the high temperatures applied in the frying of foods because of the different reaction mechanisms involved at frying conditions (Velasco and Dobarganes, 2002). The Rancimat results for the starting oils were similar, even though both oils showed quite different amounts of antioxidants. In contrast, Yousfi et al. (2006) found that changes in oil stability and phenolic compounds in olive oils during fruit ripening strongly differed according to the variety and the maturity level of the fruit. The Cornicabra virgin oils of the present study showed higher initial oxidative stability than the Picual virgin oils tested in a previous study (Olivero-David et al., 2014). This may be attributed in part to the lower amount of linoleic acid and higher content in oleic acid in the Cornicabra oils.

\section{CONCLUSIONS}

Even though the VOO obtained from Cornicabra olives with lower ripening index presented higher amounts of polyphenols and tocopherols, the two VOOs studied showed similar frying performance. This seemed to depend more on the low initial level of linoleic acid and the high oleic acid-to-linoleic acid ratio, which were similar for the two oils, than on differences in the polyphenol and/or tocopherol contents. Despite the discontinuous addition of fresh oil, the antioxidants tocopherols and polyphenols rapidly disappeared at frying conditions. As oil potential toxicity is ascribed to the level and composition of the oxidation compounds, the use of Cornicabra oils for potato frying is recommended due to their high stability.

\section{ACKNOWLEDGMENTS}

The study was granted by an INIA RTA201000097 project. We thank the FPI INIA fellowship associated to the former project given to Carmen Mena.

\section{REFERENCES}

Alba-Mendoza J, Hidalgo-Casado F, Ruiz-Gómez MA, Martínez-Román F, Moyano-Pérez MJ, Cert A, PérezCamino MC, Ruiz-Méndez MV. 1996. Characteristics of the olive oils obtained from the first and second centrifugations. Grasas Aceites 47, 163-181. http://dx.doi. org/10.3989/gya.1996.v47.i3.857

AOAC. 1995. Official methods of analysis, 16th ed. Association of Official Analytical Chemists (AOAC), Washington, DC, USA, part 969.63 .

Barrera-Arellano D, Ruiz-Méndez V, Velasco J, Márquez-Ruiz $G$, Dobarganes C. 2002. Loss of tocopherols and formation of degradation compounds at frying temperatures in oils differing in degree of unsaturation and natural antioxidant content. J. Sci. Food Agric. 82, 1696-1702. http:// dx.doi.org/10.1002/jsfa.1245

Bastida S, Sanchez-Muniz FJ. 2001. Thermal oxidation of olive oil, sunflower oil and mix of both during forty discontinuous domestic fryings of different foods. Food Sci. Technol. Int. 7, 15-21. https://doi.org/10.1106/1898-PLW3-6Y6H-8K22

Beltrán GC, Aguilera C, Del Rio C, Sánchez S, Martínez L. 2005. Influence of fruit ripening process on the natural antioxidant content of Hojiblanca virgin olive oils. Food Chem. 89, 207-215. https://doi.org/10.1016/j.foodchem.2004.02.027

Boskou D. 2011. Non-nutrient antioxidants and stability of frying oils, in Boskou D \& Elmadfa I (Eds) Frying of Foods: Oxidation, Nutrient and Non-nutrient Antioxidants, Biologically Active Compounds and High Temperatures. Taylor and Francis Group, Boca Raton, FL, USA, 199-223.

Casal S, Malheiro R, Sendas A, Oliveira BP, Pereira JA. 2010. Olive oil stability under deep-frying conditions. Food Chem. Toxicol. 48, 2972-2979. http://doi.org/10.1016/j. fct.2010.07.036

Conde C, Delrot S. Gerós H. 2008. Physiological, biochemical and molecular changes occurring during olive development and ripening. J. Plant Physiol. 165, 1545-1562. http:// doi.org/10.1016/j.jplph.2008.04.018

DGF (German Society for Fat Research). 2000. Proceedings of the 3rd international symposium of deep-fat frying. Final recommendations. Eur. J. Lipid Sci. Technol. 102, 594.

Dobarganes C, Márquez-Ruiz G. 2013. Analysis of used frying oils. Lipid Technol. 25, 159-162. http://dx.doi.org/10.1002/ lite. 201300284

Dobarganes MC, Márquez-Ruiz G. 2007. Formation and analysis of oxidized monomeric, dimeric and higher oligomeric triglycerides, in Erickson MD (Ed.) Deep Frying: Chemistry, Nutrition and Practical Applications. American Oil Chemists' Society Press, Champaign, IL, USA, 87-110.

Dobarganes MC, Pérez-Camino MC, Márquez-Ruiz G. 1988. High performance size exclusion chromatography of polar compounds in heated and non-heated fats. Lipid/Fett $\mathbf{9 0}$, 308-311. http://dx.doi.org/10.1002/lipi.19880900805

Dobarganes MC, Velasco J, Dieffenbacher A. 2000. Determination of polar compounds, polymerized an oxidized triacyglycerols, and diacylglycerols in oils and fats. Pure Appl. Chem. 72, 1563-1575. https://doi.org/10.1351/ pac200072081563

Firestone D. 1998. Official methods and recommended practices of the American Oil Chemists' Society, 5th edn. American Oil Chemists' Society Press, Champaign, IL, USA.

IUPAC. 1992. Standard methods for the analysis of oils, fats and derivatives. Pergamon, Oxford, Regulation no. 2432.

Lumley ID. 1988. Polar compounds in heated oil, in Varela G. \& Bender AE (Eds) Frying of Food. Principles, Changes, New Approaches. Ellis Horwood LTD, Chichester, UK, 166-173.

Márquez-Ruiz G, Tasioula-Margari M, Dobarganes MC. 1995. Quantitation and distribution of altered fatty acids in frying fats. J. Am. Oil Chem. Soc. 72, 1171-1176. https://doi. org/10.1007/BF02540984

Olivero-David R, Mena C, Pérez-Jimenez MA, Sastre B, Bastida S, Márquez-Ruiz G, Sánchez-Muniz FJ. 2014. Influence of Picual olive ripening on virgin olive oil alteration and stability during potato frying. J. Agric. Food Chem. 62, 11637-11646. http://dx.doi.org/10.1021/jf503860j 
Olivero-David R, Paduano A, Fogliano V, Vitaglione P, Bastida S, González-Muñoz MJ, Benedí J, Sacchi R, SánchezMuniz MJ. 2011. Effect of thermally oxidized oil and fasting status on the short-term digestibility of ketolinoleic acids and total oxidized fatty acids in rats. J. Agric. Food Chem. 59, 4684-4691. http://dx.doi.org/10.1021/jf1048063

Romero A, Cuesta C, Sánchez-Muniz FJ. 1995. Quantitation and distribution of polar compounds in an extra virgin olive oil used in fryings with turnover of fresh oil. LipidlFett 97, 403-407. http://dx.doi.org/10.1002/lipi.2700971102

Romero A, Cuesta C, Sánchez-Muniz FJ. 2000. Deep fat frying of frozen foods in sunflower oil. Fatty acid composition in fryer oil and frozen prefried potatoes. J. Sci. Food Agric. 80, 2135-2141. http://dx.doi.org/10.1002/10970010(200011)80:14<2135::AID-JSFA739>3.0.CO;2-K

Romero A, Cuesta C, Sánchez-Muniz FJ. 2003. Cyclic fatty acid monomers in high oleic sunflower oil and extra virgin olive oil used in repeated frying of fresh potatoes. $J$. Am. Oil Chem. Soc. 80, 437-442. https://doi.org/10.1007/ s11746-003-0717-x

Salvador MD, Aranda F, Gómez-Alonso S, Fregapane G. 2001a. Cornicabra virgin olive oil: a study of five crop seasons. Composition, quality and oxidative stability. Food Chem. 74, 267-274. https://doi.org/10.1016/ S0308-8146(01)00148-0

Salvador MD, Aranda F, Fregapane G. 2001b. Influence of fruit ripening on "Cornicabra" virgin olive oil quality. A study of four successive crop seasons. Food Chem. 73, 45-53. https://doi.org/10.1016/S0308-8146(00)00276-4

Sánchez-Casas J, Osorio E, Montaño A, Martínez M. 2003. Estudio del contenido en ácidos grasos de aceites monovarietales elaborados a partir de aceitunas producidas en la región extremeña. Grasas Aceites 54, 371-377.

Sánchez-Muniz FJ, Bastida S, Márquez-Ruiz G, Dobarganes C. 2008. Effects of heating and frying on oil and food fatty acids, in Chow CK (Ed.) Fatty Acids Foods and their Implications. Taylor and Francis Group, Boca Raton, FL, USA, 511-543.

Servili M, Selvaggini R, Esposto S, Taticchi A, Montedoro GF, Morozzi G. 2004. Health and sensory properties of virgin olive oil hydrophilic phenols: agronomic and technological aspects of production that affect their occurrence in the oil. J. Chromatogr. B 1054, 113-127. http://dx.doi. org/10.1016/j.chroma.2004.08.070

Škevin D, Rade D, Štrucelj D, Mokrovšak Z, Neđeral S, Benčić D. 2003. The influence of variety and harvest time on the bitterness and phenolic compounds of olive oil. Eur. J. Lipid Sci. Technol. 105, 536-541. http://dx.doi. org/10.1002/ejlt.200300782

Uceda M, Frias L. 1975. Época de recolección. Evolución del contenido graso y de la composición y la calidad del aceite, in: Proceedings II Seminario Oleícola Internacional, Córdoba, Spain.

Vázquez-Roncero A, Janer C, Janer ML. 1975. Determinación de polifenoles totales del aceite de oliva. Grasas Aceites 24, 350-355.

Velasco J, Dobarganes C. 2002. Oxidative stability of virgin olive oil. Eur. J. Lipid Sci. Technol. 104, 661-676. http://dx.doi. org/10.1002/1438-9312(200210)104:9/10<661::AIDEJLT661>3.0.CO;2-D

Velasco J, Marmesat S, Berdeaux O, Márquez-Ruiz G, Dobarganes C. 2005. Quantitation of short-chain glycerolbound compounds in thermoxidized and used frying oils. A monitoring study during thermoxidation of olive and sunflower oils. J. Agric. Food Chem. 53, 4006-4011. http:// dx.doi.org/10.1021/jf050050t

Yousfi K, Cert RM, García JM. 2006. Changes in quality and phenolic compounds of virgin olive oils during objectively described fruit maturation. Eur. Food Res. Technol. 223, 117-124. http://doi.org/10.1007/s00217-005-0160-5 